oppose the introduction into science of a correct and intelligible way of indicating the sounds of the human voice? How long will the American men of science who control scientific societies and scientific institutions and scientific journals, ignore or suppress the proposals of philological scholars to provide a definite system of indicating the sounds of the English language? How long will they oppose the movement to bring about a regulation of English spelling, so that English words may be spelt correctly and intelligibly, and so that a given man of science, in a journal devoted to science, and bearing the name of ScIEnce may present a simple idea, in simple letters, in a sure and certain way? How long? Ask our respected friends President $\mathrm{X}$ and Professor $\mathrm{Y}$ and Dr. Z, Editor $\mathrm{P}$ and Director Q, who sit at the gates of science, and scrutinize the tickets, and exclude every man who does not spell according to their Mohammedan way. In the name of the Prophet, phigs!

In the meantime the leaders in science will be writing in Science statements about language that are in fact futile, because, as we lawyers say, they are "void for uncertainty."

Of course I know, and you know, Mr. Editor, what Dr. Shull means when he says "pronounced gēn"; but we know it by a process of inference, and by a course of special study. No one else can tell what he means, except through the same process. The man of science wishes to be clear, but his collergues won't let him. In the name of the Prophet, phigs!

YoNkERS, N. Y.,

June 24, 1912

\section{FORMATION OF SPURRED FLOWERS IN HYBRID CALCEOLARIAS}

WEBBER $^{1}$ refers to hybridization as the apparent causal agent in the development of a marked spur or horn on the lip of a hybrid Calceolaria. Characters apparently new are said to appear rather commonly in hybrids and the idea is advanced that the teratological structure just mentioned may be a new unit character of the genus Calceolaria. The statement is made that " no such character, so far

${ }^{1}$ SCIENCE, N. S., 35, p. 606, April 19, 1912. as can be learned, is known in the Calceolarias, and it would seem to have been caused by the hybridization."

M. T. Masters ${ }^{2}$ states that the formation of spurs or spur-like tubes is very frequent in some seasons in the corolla of certain Calceolarias ( $C$. floribunda). An excellent figure (Fig. 169) is also given.

OrLAND E. White

$$
\begin{aligned}
& \text { Bussex Institution, } \\
& \text { HaRvard University, } \\
& \text { June 18, } 1912
\end{aligned}
$$

\section{SCIENTIFIC BOOKS}

High School Education. Edited by Charles Hughes Johnston, Ph.D. Charles Scribner's Sons. 1912.

To designate this book a notable effort in pioneer-work is to indicate at once its merits and its inevitable limitations. In its arrangement, in the assignment of general and of specific topics to writers whose interests concentrate in their respective fields of inquiry, it proclaims the fundamental belief that no single writer can hope to do justice to all the issues involved in secondary education. Where questions of general policy, of programs of study, of curricula and of method in individual subjects must be weighed to promote the ideals of efficiency, it is desirable that the inquiring teacher shall have the guidance of a number of experts whose utterances will help him to plot his own line of procedure. It speaks well for the firmness of the editor that his collaborators represent almost without exception a uniform tendency, though they are permitted full leeway in the advocacy of their individuality. Professor Johnston has on the whole been fortunate in the choice of his. cooperating writers; even for some of the subjects that have not yet found general recognition in our high schools he has secured contributors of distinctly originative ability. Even though this book may be superseded before long by similar studies of greater value, it may claim the merit of having led the way to a proper consideration of the manifold problems of the secondary school.

$$
2 \text { " Vegetable Teratology," 1869, p. } 316 .
$$

